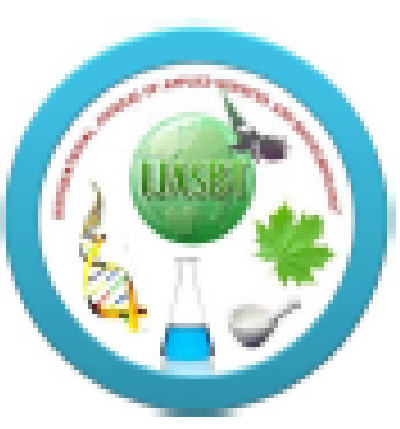

Avalable online at wwaljasht.org.

International Journal of Applied Sciences and Biotechnology A Rapid Publishing Journal

\begin{tabular}{|c|c|c|}
\hline \multicolumn{2}{|c|}{ APPUED SCIENCES } & BIOIECHNOLOSY \\
\hline $\begin{array}{l}\text { Biochemistry } \\
\text { Molecular biology } \\
\text { Microbialogy } \\
\text { Cefl bialogy }\end{array}$ & $\begin{array}{l}\text { Immunobiology } \\
\text { Biolnformatics } \\
\text { Novel drug delivery rytem } \\
\text { Pharmacology }\end{array}$ & $\begin{array}{l}\text { Microbial biotechnology } \\
\text { Med labl biotech nology } \\
\text { Industrial biotechnology } \\
\text { Enviranmental biotechnolony }\end{array}$ \\
\hline $\begin{array}{l}\text { Cytology } \\
\text { Genctics } \\
\text { Patholosy } \\
\text { Medicinal chemistry } \\
\text { Polymer sdences } \\
\text { Analytical chemistry } \\
\text { Natural chemistry }\end{array}$ & $\begin{array}{l}\text { Neu roblology } \\
\text { Biophysics } \\
\text { Botany } \\
\text { Zoology } \\
\text { Allied science } \\
\text { Earth sdence }\end{array}$ & Nanotechnology \\
\hline
\end{tabular}

If any queries or feedback, then don't hesitate to mail us at: editor.jiasbtîgmail.com 


\title{
CHARACTERIZATION AND OPTIMIZATION OF 1- AMINOCYCLOPROPANE-1-CARBOXYLATE DEAMINASE (ACCD) ACTIVITY IN DIFFERENT RHIZOSPHERIC PGPR ALONG WITH MICROBACTERIUM SP. STRAIN ECI-12A
}

\author{
Umesh P. Shrivastava ${ }^{1} *$ and Ashok Kumar ${ }^{2}$ \\ ${ }^{1 *}$ Department of Botany, Tribhuvan University, TRM Campus, Birganj, Nepal \\ ${ }^{2}$ School of Biotechnology, Banaras Hindu University, Varanasi-221005, India \\ *Corresponding author email: upshrivastava@gmail.com
}

\begin{abstract}
A total of nine strains of plant growth promoting rhizobacteria were analyzed for ACC deaminase activity, where highest ACC deaminase activity was found in Klebsiella sp strain ECI-10A (539.1 nmol $\alpha$-keto butyrate/ $\mathrm{mg}$ protein/ h) and lowest in Microbacterium sp strain ECI-12A (122.0 nmol $\alpha$-keto butyrate/ mg protein/h). Although Microbacterium sp strain ECI-12A showed lowest level of ACC deaminase activity, but, the species of Microbacterium isolated from rhizosphere is the first report. Microbacterium sp strain ECI-12A was also analyzed under varying conditions of time, amount of 1-Aminocyclopropane-1carboxylate (ACC), and temperature for optimization of the ACC deaminase activity. The optimum activity was recorded with the supplementation of $5 \mathrm{mM} \mathrm{ACC}$ at $30^{\circ} \mathrm{C}$ temperature after $24 \mathrm{~h}$ of culture growth. All the nine strains showed acdS gene in the PCR amplification of that gene. No any rhizospheric Microbacterium species showing ACC deaminase activity have been reported earlier, therefore, we report here ACC deaminase activity in Microbacterium sp ECI-12A isolated from rice rhizosphere is a novel finding.
\end{abstract}

Key words: ACC deaminase activity, rhizospheric bacteria, Microbacterium sp, PGPR.

\section{Introduction}

1-Aminocyclopropane-1-carboxylate

(ACC) deaminase, an enzyme capable of hydrolyzing ACC, the immediate precursor of ethylene was firstly reported in 1978, which was isolated from Pseudomonas sp. strain ACP (Honma and Shimomura, 1978). The ACC deaminase has been detected in the fungus, Penicillium citrinum and in a number of bacteria (Ma et al., 2003; Blaha et al., 2006; Madhaiyan et al., 2006; Belimov et al., 2007). The gene responsible for ACC deaminase activity (acdS) has been recently found in Azopirillum., Burkholderia cepacia genomovars (which include PGPR, phytopathogens and opportunistic human pathogens), and Agrobacterium genomovars (Blaha et al., 2006). These microorganisms were identified by their ability to grow on minimal medium containing ACC as its sole nitrogen source (Honma and Shimomura, 1978; Belimov et al., 2007; Ma et al., 2003).

The plant growth-promoting bacterium, Pseudomonas putida GR12-2, which contains the enzyme ACC deaminase, stimulates root elongation (Glick et al., 1994) and significantly reduces the level of ACC in emerging roots and shoots. Three separate mutants of Pseudomonas putida GR12-2, deficient in ACC deaminase activity, were reported to lose the ability to promote canola root elongation under gnotobiotic conditions (Glick et al., 1994). The ACC in the exudates may be taken up by the bacteria and subsequently hydrolyzed by the enzyme, ACC deaminase, to ammonia and $\alpha$-ketobutyrate. The uptake and cleavage of ACC by plant growth-promoting bacteria decrease the amount of ACC outside the plant. Increasing amounts of ACC are exuded by the plant in order to maintain the equilibrium between interna1 and external ACC levels. It is proposed that plant growthpromoting bacteria that possess the enzyme ACC deaminase and are bound to seeds or roots of seedlings can reduce the amount of plant ethylene and thus cause inhibition of root elongation. Thus, these plants should have longer roots and possibly longer shoots as well, in as much as stem elongation, except in flooding resistant plants, is also inhibited by ethylene (Abeles et al., 1992). Soil bacteria that have ACC deaminase activity should then have a selective advantage over other soi1 bacteria in situations in which the main bacterial nutrients are from exudates of plants (Shah $e t$ al., 1998). It should also be borne in mind that soil bacteria may acquire ACC deaminase genes by mechanisms other than fortuitous mutation-transfer of such a gene from another soil bacterium is another 
possible mechanism. The regulation of ethylene production in plants, especially to prevent increased ethylene production and accumulation, may reduce many of the inhibitory effects of this hormone (Jacobson et al., 1994). Many agricultural and horticultural crops are particularly sensitive to ethylene levels which regulate fruit ripening and control the deleterious effects of senescence in vegetables and flowers (Sisler and Serek, 1997). The bacterial enzyme, ACC deaminase, is potentially a valuable tool for controlling the levels, and hence the effects of ethylene in plants. ACC deaminase has already been used to substantially reduce ethylene levels in transgenic tomato plants which have exhibited a prolonged ripening phase (Klee et al., 1991) and to lower stress ethylene levels following infection by bacterial and fungal pathogens (Lund et al., 1998). Strains of plant growth-promoting bacteria that contain ACC deaminase are known to reduce $\mathrm{ACC}$, and hence ethylene, levels in canola seedlings (Penrose and Glick, 2003), promote root elongation in a variety of plants (Hall et al., 1996), decrease the deleterious effects of flooding on tomato plants, and prolong the shelf-life of ethylene sensitive cut flowers (Klee et al., 1991). Therefore, plant growth promoting bacteria containing ACC deaminase activity can be utilized for the improvement of crop yields. Based on our knowledge, there is no any report of Microbacterium having ACC deaminase activity present in the rhizosphere of plants, whereas, only a few endophytes has been reported for this activity. The objective of the present study was to evaluate the activity of the ACC deaminase enzyme in rhizospheric plant growth promoting rhizobacteria with special reference to Microbacterium in the various conditions. In addition to above objective, we attempted to find out the presence of $a c d S$ gene in all the strains used in this study.

\section{Materials and Methods}

\section{Bacterial strains and growth conditions}

Bacterial strains and their culture conditions of rhizospheric plant growth promoting bacteria showing nitrogen fixation, IAA production, siderophore production and P-solubilization properties were previously reported (Shrivastava, 2012). With an objective to optimize of various growth conditions for the estimation of ACC deaminase activity and amplification of acdS gene, nine most efficient strains isolated from rice rhizosphere of Indo-Nepal border region (1 Microbacterium sp strain ECI-12A; 3 Klebsiella sp strains ECI-10A, AF-4C and BN-4A; 2 Agrobacterium sp strains $\mathrm{AF}-1 \mathrm{D}$ and $\mathrm{BN}-2 \mathrm{~A} ; 2$
Pseudomonas sp strains $\mathrm{AF}-4 \mathrm{~B}$ and $\mathrm{PN}-4 \mathrm{D}$ and 1 Serratia sp strain AF-5A) were taken.

\section{Estimation of 1-Aminocyclopropane-1-Carboxylate Deaminase (ACC Deaminase) Activity}

For the measurement of ACC deaminase activity, selected isolates were grown overnight in $10 \mathrm{~mL}$ of $\mathrm{NB}$ medium and thereafter harvested by centrifugation. The pellet was washed with normal saline and suspended in $7.5 \mathrm{~mL}$ of $\mathrm{JNFb}^{-}$medium containing $5 \mathrm{mM}$ of 1 aminocyclopropane-1-carboxylate (ACC). Tubes were incubated at $28^{\circ} \mathrm{C}$ with shaking $(120 \mathrm{rpm})$ for growth. ACC served as the sole source of nitrogen in the medium. After $24 \mathrm{~h}$ of growth, cells were centrifuged at $8000 \mathrm{rpm}$ at $4^{\circ} \mathrm{C}$ for $10 \mathrm{~min}$. The pellet was suspended in $1 \mathrm{~mL}$ of $0.1 \mathrm{M}$ Tris- $\mathrm{HCl}(\mathrm{pH} 7.6)$ and again centrifuged at $15000 \mathrm{rpm}$ for $15 \mathrm{~min}$. Pellet was collected and supernatant discarded. The pellet was resuspended in $600 \mu \mathrm{L}$ of $0.1 \mathrm{M}$ Tris- $\mathrm{HCl}(\mathrm{pH} 8.5) .30$ $\mu \mathrm{L}$ of toluene was added to the cell suspension and vortexed at higher setting for $30 \mathrm{~s}$. Tube was kept at $4^{\circ} \mathrm{C}$ for $1 \mathrm{~h}$ and then centrifuged at $1200 \mathrm{rpm}$ for $10 \mathrm{~min}$ at $4^{\circ} \mathrm{C}$. The thin layer of toluene was aspirated by micro-pipette gently. Now, the toluenized cells were equally distributed in two eppendroff tubes. First part was stored at $4^{\circ} \mathrm{C}$ for protein assay and other part was used for ACC deaminase assay immediately. $200 \mu \mathrm{L}$ of toluenized cells was transferred in a fresh $1.5 \mathrm{~mL}$ microcentrifuge tube and $20 \mu \mathrm{L}$ of $0.5 \mathrm{M}$ ACC was added to the suspension. It was briefly vortexed and incubated at $30^{\circ} \mathrm{C}$ for $15 \mathrm{~min} .1 .0 \mathrm{~mL}$ of $0.56 \mathrm{M} \mathrm{HCl}$ was added, vortexed and centrifuged for $10 \mathrm{~min}$ at $12000 \mathrm{rpm}$. Now, $1 \mathrm{~mL}$ of the supernatant was taken in another tube and $800 \mu \mathrm{L}$ of $0.56 \mathrm{M} \mathrm{HCl}$ was added and vortexed briefly. Thereafter $300 \mu \mathrm{L}$ of 2,4 , dinitrophenylhydrazine $(2 \% \mathrm{w} / \mathrm{v})$ was added to the tube. It was mixed properly by vortexing and incubated at $30^{\circ} \mathrm{C}$ for $30 \mathrm{~min} .2 \mu \mathrm{L}$ of $2 \mathrm{M} \mathrm{NaOH}$ was added and after mixing absorbance was recorded at $540 \mathrm{~nm}$. The amount of $\mu \mathrm{mol}$ of $\alpha$-ketobutyrate produced by this reaction was determined and compared with a standard curve of $\alpha$-ketobutyrate ranging between 0.1 and 1.0 $\mu \mathrm{mol}$. For the purpose of standard curve generation a sock solution of $100 \mathrm{mM} \alpha$-ketobutyrate (SigmaAldrich Co., USA) was prepared in $0.1 \mathrm{M}$ Tris- $\mathrm{HCl} \mathrm{pH}$ 8.5 and stored at $4^{\circ} \mathrm{C}$. Enzyme activity was expressed as $\mu \mathrm{mol} / \mathrm{mg}$ protein $/ \mathrm{h}$.

\section{Amplification of acdS gene}

The primers 5'- GGCAAGGTCGACATCTATGC-3' and 5'-GGCTTGCCATTCAGCTATG-3' (Duan et al., 2009) were used to amplify $a c d S$ gene. The thermal profile for amplification was 2-min initial denaturation 
at $94^{\circ} \mathrm{C}, 35$ cycles of 1 -min denaturation at $92^{\circ} \mathrm{C}, 50-\mathrm{s}$ primer annealing at $58^{\circ} \mathrm{C}$, and 1 min of elongation at $72^{\circ} \mathrm{C}$. The amplified products were visualised with ethidium bromide stained agarose gel electrophoresis.

\section{Result and Discussions}

\section{Estimation of ACCD activity in selected isolates}

ACCD activity is indirectly responsible for growth promotion in plants; therefore, its activity was measured. Out of nine isolates tested highest activity was found in Klebsiella sp strain ECI-10A followed by Pseudomonas sp strain AF-4B. All the isolates showed activity in the range of $122-539.1 \mathrm{nmol} \alpha$ ketobutyrate/mg protein /h (Table 1).

Table 1: ACC deaminase activity in PGP strains

\begin{tabular}{lc}
\hline Bacterial strains & $\begin{array}{c}\text { ACC deaminase activity } \\
\text { (nmol } \boldsymbol{\alpha} \text {-keto butyrate/ } \\
\text { mg protein/h) }\end{array}$ \\
\hline Klebsiella sp strain ECI-10A & 539.1 \\
Microbacterium sp strain ECI-12A & 122.0 \\
Agrobacterium sp strain AF-1D & 237.3 \\
Pseudomonas sp strain AF-4B & 435.2 \\
Klebsiella sp strain AF-4C & 171.9 \\
Serratia sp strain AF-5A & 305.7 \\
Pseudomonas sp strain PN-4D & 358.4 \\
Agrobacterium sp strain BN-2A & 316.0 \\
Klebsiella sp strain BN-4A & 261.9 \\
\hline Data &
\end{tabular}

Data shown is the average of two independent experiments performed in identical conditions. The induction of ACCD activity was tested with $5 \mathrm{mM}$ ACC.

\section{Time course assay of ACCD activity}

Since all the isolates tested showed appreciable level of ACCD activity, it was desirable to test time course appearance of activity. Accordingly the Microbacterium sp strain ECI-12A was incubated in $\mathrm{JNFb}^{-}$medium containing $5 \mathrm{mM}$ ACC and ACCD activity was measured at desired time intervals $(0,4,8$, 12, 24 and 48h). It is evident from the data of Fig. 1 that there was presence of some basal activity at $0 \mathrm{~h}$ which increased with time of incubation. Activity showed linear increase from $8 \mathrm{~h}$, the maximum level was attained at $24 \mathrm{~h}$ (316.0 nmol $\alpha$-keto butyrate/mg protein $/ \mathrm{h}$ ). Beyond $24 \mathrm{~h}$ there was no significant increase; it was almost constant after $24 \mathrm{~h}$ (Fig. 1)

\section{Do varying concentrations of ACC affect activity?}

Effect of varying concentrations of ACC was tested so as to find out the optimal concentration required for the ACCD activity. It is evident from the result of Fig. 2 that there was negligible activity without ACC addition to culture, but activity started appearing with the addition of as low as $0.1 \mathrm{mM}$ ACC in the culture medium. The level of enzyme activity increased with the increasing concentrations of ACC and maximum increase was attained with $5 \mathrm{mM}$ ACC. Further increase in ACC concentration did not show any increase in activity (data not shown).

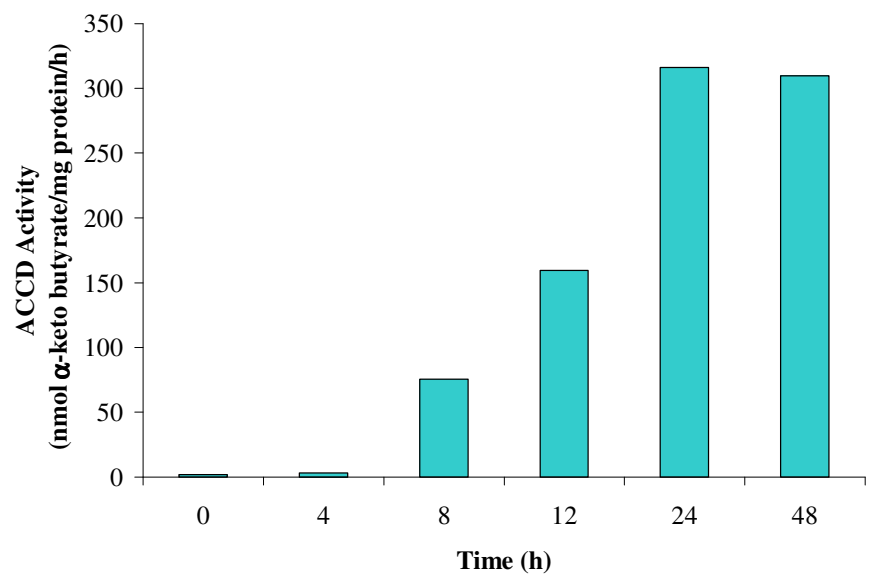

Fig. 1: Time course induction of ACCD activity in Microbacterium sp strain ECI-12A. Culture was grown with $5 \mathrm{mM}$ ACC and activity was measured at desired time intervals. Data shown is the average of two independent experiments performed separately in identical condition.

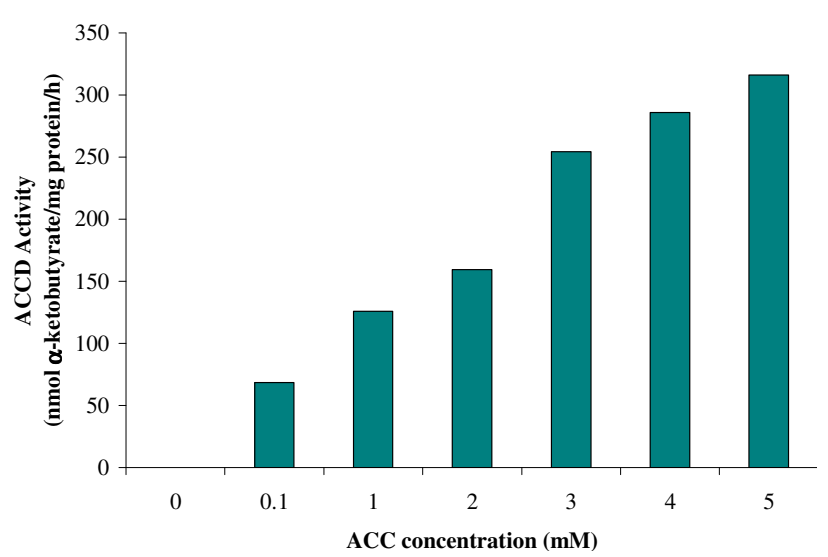

Fig. 2: ACCD activity in Microbacterium sp strain ECI$12 \mathrm{~A}$ in the presence of varying concentrations of ACC. Data shown is the average of two independent experiments performed separately in identical condition.

\section{Effect of varying temperature on ACCD activity}

Since temperature plays important role in the regulation of plant growth promoting features of any bacteria, it was desirable to test ACCD activity at varying temperature. Keeping this objective in mind, ACCD activity at varying temperature was tested in Microbacterium sp strain ECI-12A. It is evident from the data of Fig. 3 that maximum ACCD activity was observed at $30^{\circ} \mathrm{C}$ and thereafter there was decrease. Only $33.2 \%$ activity was left at $35^{\circ} \mathrm{C}$ (Fig. 3 ). 


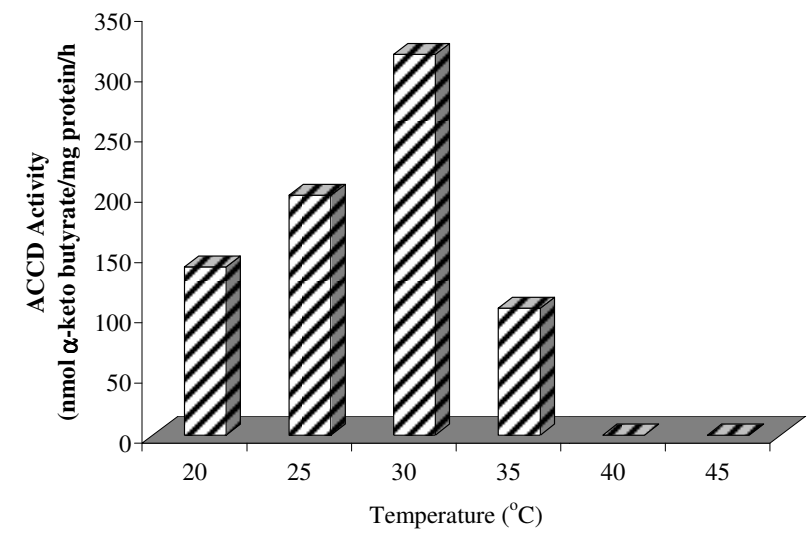

Fig. 3: ACCD activities at varying temperature in the Microbacterium sp strain ECI-12A.

\section{Amplification of acdS gene}

The PCR amplification of acdS gene responsible for ACCD activity was done in all the nine isolates. It is evident from the gel photograph (Fig. 4) that all the isolates showed amplicon of acdS gene $(\sim 1.0 \mathrm{~kb})$.

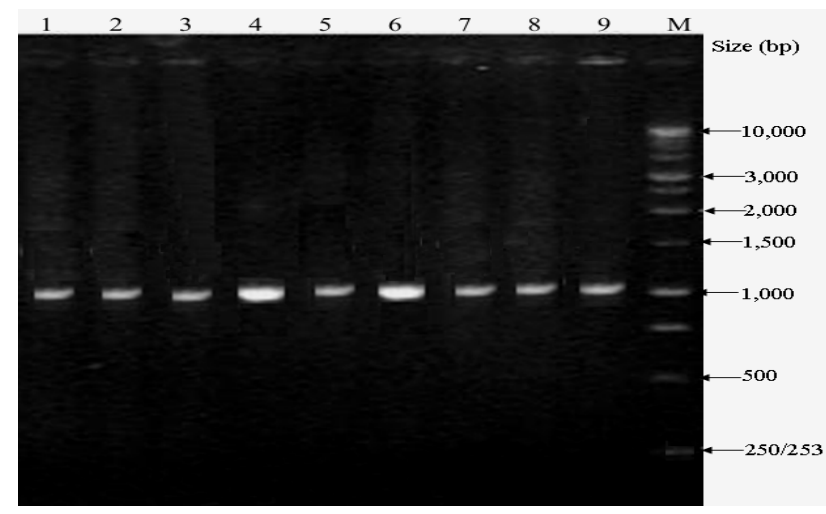

Fig. 4: Agarose gel photograph showing acdS gene fragment $(1.0 \mathrm{~kb})$ in nine selected isolates. Lane 1 to 9: acdS gene fragment of various strains (Klebsiella sp strain ECI-10A, Microbacterium sp strain ECI-12A, Agrobacterium sp strain AF-1D, Pseudomonas sp strain AF-4B, Serratia sp strain AF-5A, Klebsiella sp strain AF-4C, Pseudomonas sp strain PN-4D, Agrobacterium sp strain $\mathrm{BN}-2 \mathrm{~A}$, and Klebsiella $\mathrm{sp}$ strain BN-4A); M: $1.0 \mathrm{~kb}$ DNA marker.

Amelioration of salt stress has been reported in canola (Brassica napus L.) growth by the ACCD containing fluorescent pseudomonads (Jalili et al., 2009). Prevalence of ACC deaminase activity in various PGPR including Enteobacter cloacae (Belimov et al., 2005), Pseudomonas sp ACP (Sheehy et al., 1991), Serratia quinivorans SUD165 (Belimov et al., 2005), Pseudomonas putida strain UW4 (Shah et al., 1998) and Klebsiella pneumonie strain Kp 342 (Iniguez et al., 2005) as well as certain yeast and fungi (Yao et al., 1995) has been reported. Results of the present finding are in agreement with above reports since isolates reported here in also belong to the genus Klebsiella sp
(AF-4C and BN-4A), Pseudomonas sp (AF-4B and PN-4D), Serratia sp (AF-5A) and Agrobacterium sp (AF-1D and BN-2A). However presence of ACC deaminase activity in the Microbacterium species has not been reported from rhizosphere of any plant except a few reports from endophytic bacteria. Endophytic Microbacterium sp G16 isolated from rape (Brassica napus) roots showed ACC deaminase activity (Sheng et al., 2009), whereas ACC deaminase activity showing Microbacterium sp ECI-12A isolated from rice rhizosphere is a first report. Time course study of the activity suggests that the presence of ACC in the medium is prerequisite for optimal activity of the enzyme. ACC deaminase activity plays vital role in maintaining ethylene level in any plants. ACC released exudates by roots of plants may be utilized as nitrogen source by root associated bacteria if they possess ACC deaminase enzyme. It has been reported that plants treated with ACC deaminase containing bacteria have longer roots and can show resistance to inhibitory effects of ethylene stress on plant growth. Several stresses such as flooding, heavy metals, salinity as well as pathogens are known to induce ethylene stress. Under such stresses PGPR possessing ACC deaminase activity would be useful to counteract the inhibitory effects imposed by ethylene. Furthermore, results of this study clearly show that all the nine isolates could be exploited to manage the ethylene stress if they establish colonization in root region of any plants.

\section{Acknowledgement}

The first author is thankful to ICCR, Government of India for financial supports and Tribhuvan University, Nepal for study leave. This study was partly supported by a research grant sanctioned to Prof. Ashok Kumar (the second author), ICAR, New Delhi (No. NBAIM/AMAAS/MD(19)/AK/BG, New Delhi).

\section{References}

Abeles FB, Morgan PW and Saltveit ME (1992) Ethylene in Plant Biology. Academic press, San Diego.

Belimov AA, Dodd IC, Safronova VI, Hontzeas N and Davies WJ (2007) Pseudomonas brassicacearum strain AM3 containing 1-aminocyclopropane-1carboxylate deaminase can show both pathogenic and growth-promoting properties in its interaction with tomato. J. Exp. Bot. 58:1485-1495.

Belimov AA, Hontzeas N, Safronova VI, Demchinskaya SV, Piluzza G, Bullitta S and Glick BR (2005) Cadmium-tolerant plant growth-promoting bacteria associated with the roots of Indian mustard (Brassica juncea L. Czern.). Soil Biol. Biochem. 37:241-250.

Blaha D, Prigent-Combaret C, Mirza MS and MoenneLoccoz Y (2006) Phylogeny of the 1aminocyclopropane-1-carboxylic acid deaminase- 
Shrivastava UP and Kumar A (2013). Int J Appl Sci Biotechnol, Vol. 1(1): 11-15

encoding gene $a c d S$ in phytobeneficial and pathogenic proteobacteria and relation with strain biogeography. FEMS Microbiol. Ecol. 56:455-470.

Duan J, Muller KM, Charles TC, Vesely S and Glick BR (2009) 1-aminocyclopropane-1-carboxylic acid deaminase genes in Rhizobia from southeren Saskatchewan. Microb. Ecol. 57: 423-436

Fallik E, Okon Y, Epstein E, Goldman A and Fischer M (1989) Identification and quantification of IAA and IBA in Azospirillum-brasilense-inoculated maize roots. Soil. Biol. Biochem. 21:147-153.

Glick BR, Jacobson CB, Schwarze MMK and Pasternak JJ (1994) 1-aminocyclopropane-1-carboxylic acid deaminase mutants of the plant-growth promoting rhizobacterium Pseudomonas putida GR12-2 do not stimulate canola root elongation. Can. J. Microbiol. 40:911-915.

Glick BR, Liu CP, Ghosh S and Dumbroff EB (1997) Early development of canola seedlings in the presence of the plant growth-promoting rhizobacterium Pseudomonas putida GR12-2. Soil Biol. Biochem. 29:1233-1239.

Hall JA, Peirson D, Ghosh S and Glick BR (1996) Root elongation in various agronomic crops by the plant growth promoting rhizobacterium Pseudomonas putida GR12-2. Israel J. Plant Sci. 44:37-42.

Honma M and Shimomura T (1978) Metabolism of 1aminocyclopropane-1-carboxylic acid. Agric. Biol. Chem. 42:1825-1831.

Iniguez AL, Dong YM, Carter HD, Ahmer BMM, Stone JM and Triplett EW (2005) Regulation of enteric endophytic bacterial colonization by plant defenses. Mol Plant-Microbe Interact. 18:169-178.

Jacobson CB, Pasternak JJ and Glick BR (1994) Partial purification and characterization of 1aminocyclopropane-1-carboxylate deaminase from the plant-growth promoting rhizobacterium Pseudomonas putida GR12-2. Can. J. Microbiol. 40:1019-1025.

Jalili F, Khavazi K, Pazira E, Nejati A, Rahmani HA, Sadaghiani HR and Miransari M (2009) Isolation and characterization of ACC deaminase-producing fluorescent Pseudomonads, to alleviate salinity stress on canola (Brassica napus L.) growth. J. Plant. Physiol. 166:667-674.

Klee HJ, Hayford MB, Kretzmer KA, Barry GF and Kishore GM (1991) Control of ethylene synthesis by expression of a bacterial enzyme in transgenic tomato plants. Plant Cell 3:1187-1193.

Lund ST, Stall RE and Klee HJ (1998) Ethylene regulates the susceptible response to pathogen infection in tomato. Plant Cell 10:371-382.
Ma WB, Sebestianova SB, Sebestian J, Burd GI, Guinel FC and Glick BR (2003) Prevalence of 1aminocyclopropane-1-carboxylate deaminase in Rhizobium spp. Antonie Van Leeuwenhoek 83:285291.

Madhaiyan M, Poonguzhali S, Ryu J and Sa T (2006) Regulation of ethylene levels in canola (Brassica campestris) by 1-aminocyclopropane-1-carboxylate deaminase-containing fujisawaense. Planta 224:268-278.

Patten CL and Glick BR (1996) Bacterial biosynthesis on indole-3-acetic acid. Can. J. Microbiol .42:207220.

Penrose DM and Glick BR (2003) Methods for isolating and characterizing ACC deaminase-containing plant growth-promoting rhizobacteria. Physiologia Plantarum 118:10-15.

Shah S, Li JP, Moffatt BA and Glick BR (1998) Isolation and characterization of ACC deaminase genes from two different plant growth-promoting rhizobacteria. Can. J. Microbiol. 44:833-843.

Sheehy RE, Honma M, Yamada M, Sasaki T, Martineau B and Hiatt WR (1991) Isolation, sequence, and expression in Escherichia-coli of the Pseudomonas sp strain ACP gene encoding 1aminocyclopropane-1-carboxylate deaminase. $J$. Bacteriol. 173:5260-5265.

Sheng XF, He LY, Zhou L, and Shen YY (2009) Characterization of Microbacterium sp. F10a and its role in polycyclic aromatic hydrocarbon removal in low-temperature soil. Can J Microbiol 55: 529535 .

Shrivastava UP (2012) Molecular Study of Rice Plant Rhizobacteria of Indo-Nepal Border. LAP LAMBERT Academic Publishing GmbH \& Co. KG, Heinrich-Böcking-Str. 6-8, 66121 Saarbrücken, Germany

Sisler EC and Serek M (1997) Inhibitors of ethylene responses in plants at the receptor level: Recent developments. Physiologia Plantarum 100:577582.

Xie H, Pasternak JJ and Glick BR (1996) Isolation and characterization of mutants of the plant growthpromoting rhizobacterium Pseudomonas putida CR12-2 that overproduce indoleacetic acid. Curr Microbiol 32:67-71.

Yao M, Horiuchi A, Tanaka I and Honma M (1995) Crystallization of 1-aminocyclopropane-1carboxylic acid deaminase from yeast. Protein Peptide Lett. 2:305-30. 